\title{
Electrical Resistance of Wood Tissue and Water Relation Parameters of Leaves in "Over-Year Wilt" of Pines Induced by Pine Wilt Disease
}

\author{
Kenji FukUdA* and Kazuo Suzukı*
}

Key words: "over-year wilt", pine wilt disease, electrical resistance, $P$ - $V$ analysis.

Pine wilt disease caused by Bursaphelenchus xylophilus (Steiner et Buhrer) Nickle is the most serious epidemic disease of Japanese red pine, Pinus densiflora Sieb. et Zucc., and Japanese black pine, Pinus thunbergii Parl., and now is spreading to the northern part of Japan. In the southwestern Japan, most trees infected with pine wood nematode die within the year of infection, however, in the newly infested low temperature regions, such as Tohoku district, the disease develops more gradually, and most of infected trees remain alive throughout the winter, and die in the following spring 1, 2). We call this phenomenon "over-year wilt" of pines.

In these cases, cessation of oleoresin exudation and attack of a pine sawyer, Monochamus alternatus Hope, and a wood wasp, Sirex nitobei Matsumura, are often observed in the autumn. To clarify the physiological processes in the infected trees in the course of disease development from the infection of summer to the death of spring is not only of a scientific interest, but also of an urgent political demand for prediction of the over-year wilt of pines.

For this purpose, some investigations were made about the physiological status of Japanese red pine, naturally infected with pine wood nematodes. And the water relation parameters of leaves and electrical resistance of wood tissue are discussed as the disease develops.

Investigations were made at a 32 33 year-old Japanese red pine stand $100 \mathrm{~m}$ above the sea level, at Ichinoseki, northern part of Japan. Thirteen trees were selected for the investigations in September 29, 1986.

Table 1 shows symptoms of the trees examined from September 1986 to June 1987. Trees diagnosed as healthy throughout the investigation period were designated $\mathrm{H}-1 \sim 4$. Trees with some disorder but which didn't die in the period were designated S-1 6. Trees dead or dying in the spring of 1987 were designated D-1 3.

In S-1, cessation of oleoresin exudation and yellowing of leaves were observed in September 1986, and foliage symptom developed in winter. In S-2 and S-3, death of crown top was observed in September 1986, but they showed no advances in symptoms during the investigation period. S-4 6 are trees which were attacked by some wood- and bark-boring insects during the investigation period, but showed neither foliage nor resin symptoms.

In D-1 and D-2, foliage symptoms were observed in September 1986, and advanced gradually in winter, and in D-3, the disease symptoms developed clearly in the spring of 1987. In these trees, an oviposition of a wood wasp, Sirex nitobei, and attack by a bark beetle, Tomicus piniperda Linné, were observed in the autumn of 1986 and the spring of 1987, respectively.

For monitoring the changes in microflora in the wood tissue of diseased trees, electrical resistance (ER) was measured after Suzuki et al. ${ }^{3)}$ The measurements were made in each 5

* Faculty of Agriculture, University of Tokyo, Bunkyo-ku, Tokyo 113, Japan 東京大学農学部

1) Jinno, Y. (1984). Forest Pests 33: 4-8. 2) Kishi, Y. (1980). Bull. Ibaraki Pref. For. Exp. Stn. 11: 1-83. 3) Suzuki, K., Yoshida, N., Dozono, Y., Hashimoto, H. and Kobayashi, T. (1984). Bull. For. For. Prod. Res. Inst. 328: 107-117. 
Table 1. Symptom development in Japanese red pine trees

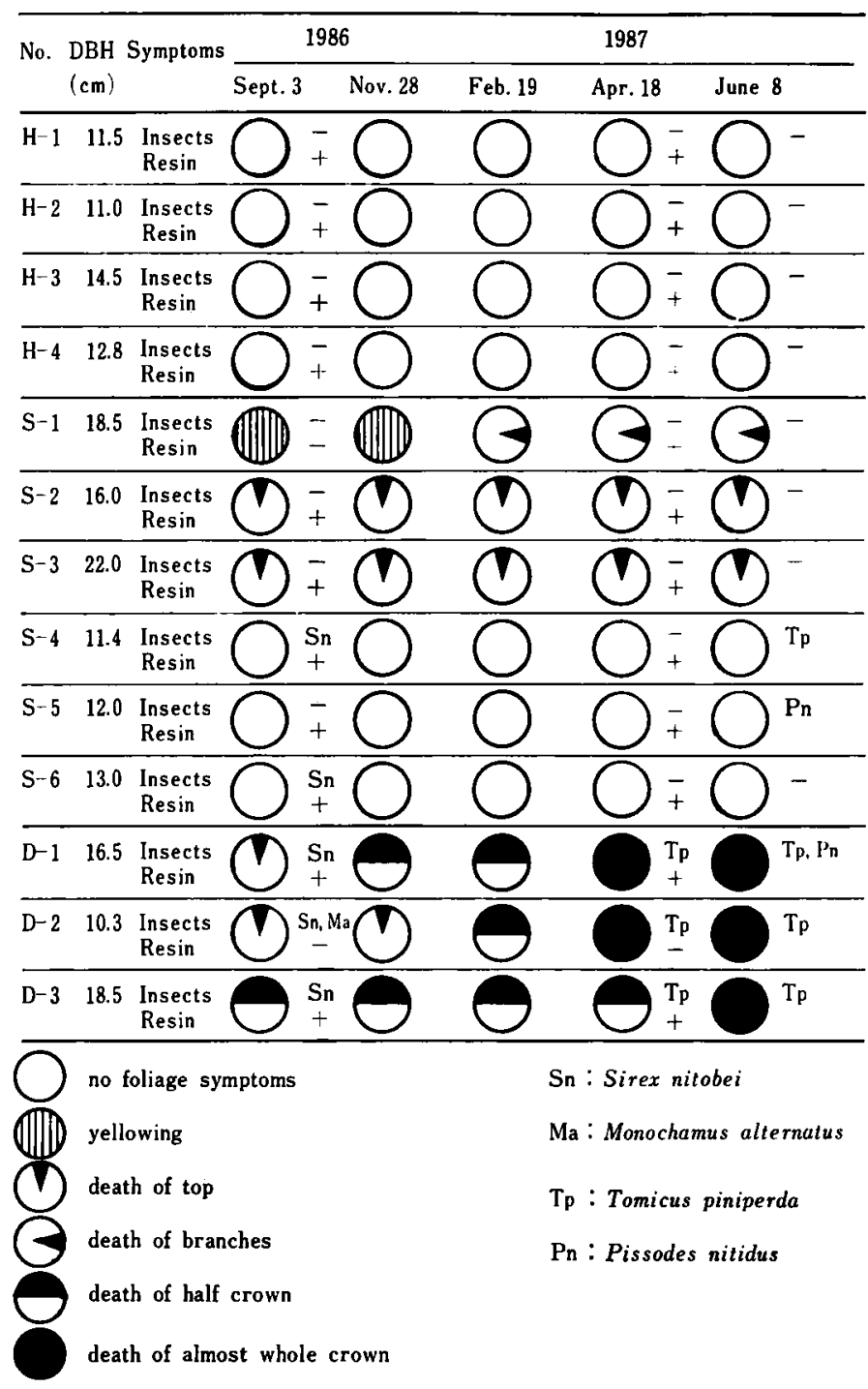

$\mathrm{cm}$ depth of the trunk from the cambia inserting the probe into a drilled hole of $6 \mathrm{~mm}$ diameter. ER value to direct current less than $180 \sim 200 \mathrm{k} \Omega$ is considered to indicate the discolored or decayed woods as in the previous paper ${ }^{3)}$. Table 2 shows the minimum ER values of each tree during the investigation period. Until April 27, all of the examined trees except D-3 in September 29 , showed high ER values above $180 \mathrm{k} \Omega$. In June 9, all of the five trees $(\mathrm{S}-1, \mathrm{~S}-4, \mathrm{~S}-5$, D-2, D-3) with low ER values showed some disorder or death (Table 1). However, D-1 showed high ER values throughout the period with a heavy chlorosis and necrosis of the whole crown.

These results suggest that changes in microflora in wood tissue were not accompanied with various symptoms in winter.

In pine wilt disease, water stress plays an important role in disease development ${ }^{4)}$ and water relation parameters in diseased tree show some char acteristic changes such as an increase in bulk 
Table 2. Electrical resistance $(\mathrm{k} \Omega)$ of wood tissue in Japanese red pine trees

\begin{tabular}{|c|c|c|c|c|c|}
\hline \multirow{2}{*}{ No. } & \multicolumn{2}{|c|}{1986} & \multicolumn{3}{|c|}{1987} \\
\hline & Sept. 29 & Nov. 28 & Feb. 10 & Apr. 27 & June 9 \\
\hline H-1 & 290 & 400 & 220 & 220 & 180 \\
\hline H-2 & 210 & 400 & 320 & 270 & 250 \\
\hline H-3 & 230 & 280 & 180 & 500 & 210 \\
\hline $\mathrm{H}-4$ & 360 & 380 & 350 & 470 & 270 \\
\hline S-1 & 270 & 300 & 240 & 400 & 160 \\
\hline S-2 & 350 & 500 & 360 & 700 & 500 \\
\hline S-3 & 450 & 320 & 300 & 270 & 200 \\
\hline S-4 & 320 & 600 & 430 & 280 & 160 \\
\hline S-5 & 250 & 650 & 450 & 350 & 160 \\
\hline S-6 & 300 & 450 & 320 & 400 & 230 \\
\hline D-1 & 450 & 350 & 350 & 400 & 230 \\
\hline D-2 & 410 & 250 & 600 & 350 & 130 \\
\hline D-3 & 120 & 450 & 240 & 260 & 110 \\
\hline
\end{tabular}
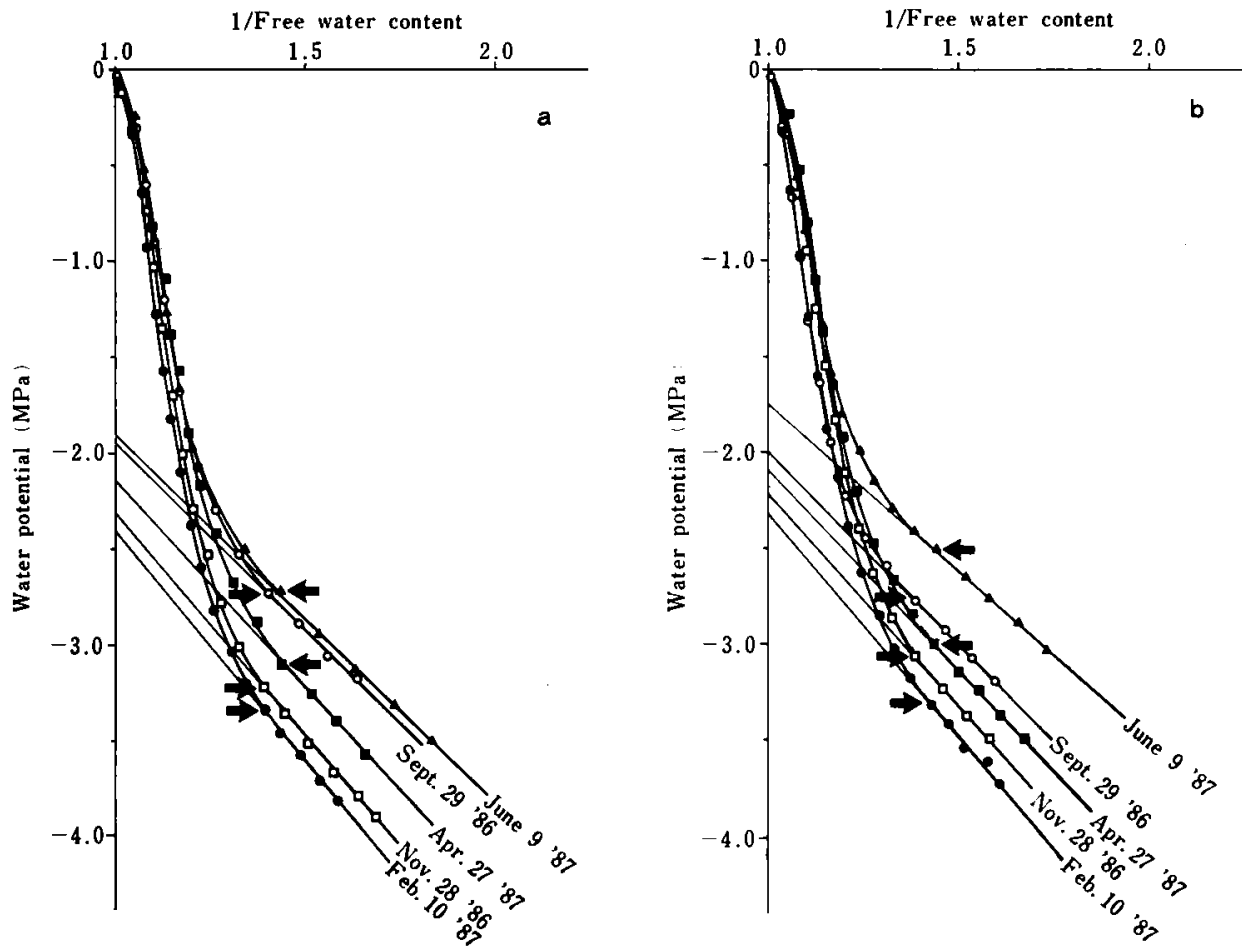

Fig. 1. $P-V$ curves in Japanese red pine trees. a: a healthy tree (H-1), b: a diseased tree (D-1). An arrow shows a turgor loss point $\left(\phi_{\mathrm{w}}^{\mathrm{tlp}}\right)$.

elastic modulus $(\varepsilon)$ of cell wall and a reduction in osmotic adjustment ${ }^{5)}$. To investigate the water relation parameters of leaves in over-year wilt of pines, pressure-volume $(P-V)$ curves $^{6,7)}$ were examined. Sample twigs were taken for $P-V$ analysis, and brought to the laboratory with

4) Suzuki, K. and Kiyohara, T. (1978). Eur. J. For. Path. 8: 97-107. 5) Fukuda, K. and Suzuki, K. (1988). J. Jpn. For. Soc. 70: 390-394. 6) Tyree, M.T. and Hammel, H.T. (1972). J. Exp. Bot. 23: 267-282. 7) Suzuki, K., Hiratsuka, Y. and Ayer, W.A. (1987). Ann. Phytopath. Soc. Japan 53: 39-44. 
sealed conditions in a plastic bag within an ice box ${ }^{8)}$. $P-V$ curves were composed within two days after sampling, and some water relation parameters were estimated such as wilting point $\left(\phi_{\mathrm{w}}^{\text {tlp }} ;\right.$ tlp: turgor loss point $\left.{ }^{7}\right)$ and bulk elastic modulus $(\varepsilon)$.

$P-V$ curves in a sound-looking tree were shown in Fig. 1a. $\phi_{\mathrm{w}}^{\text {tlp }}$ was $-2.7 \mathrm{MPa}$ in September 29 , and it decreased to $-3.3 \mathrm{MPa}$ gradually until February 10. When the winter was over, $\phi_{\mathrm{w}}^{\text {tip }}$ turned back upward in April 27, and returned to $-2.7 \mathrm{MPa}$ in June 9. These changes in $\phi_{\mathrm{w}}^{\text {tlp }}$ were regarded as a seasonal osmotic adjustment to cold hardiness ${ }^{9,10)}$.

$P-V$ curves in a pine wood nematode infested tree (Fig. 1b) showed a normal osmotic adjustment, and no remarkable differences were recognized between healthy and diseased trees. Also, no differences between healthy and diseased trees were observed in the maximum values of bulk elastic modulus ( $\varepsilon$ max) estimated from $P_{-} V$ curves.

The results suggest that physiological changes observed in ER and water relation parameters are not correlated to the development of visible symptoms during autumn and winter. And, physiological changes occur abruptly in the next spring. This is a marked characteristics on over-year wilt of pines.

The authors wish to thank Mr. Heisuke Sato, Iwate Pref. For. Exp. Stn., for investigations of the symptom development in sample trees, and to the members of the Tohoku Branch, For. For. Prod. Res. Inst, for their help.

\section{和 文 摘 要}

福田健二・鉿木和夫 : 材線虫病による年越し枯れアカマツ材部の電気抵抗值および葉の水分生理特性の経 時的变化

材線虫病による年越し枯れのアカマッについて, 病徽の進展に伴ら材部の電気抵抗值および莱の水分生理 特性の変化について検討を加えた。材部の電気抵抗值は，秋から冬にかけてはほとんとが正常な值を示した が, 感染翌年の春 初夏にかけて $180 \mathrm{k} \Omega$ 末满の值をとるものが多く、春季の材内におけるミクロフロラの 変化が示唆された。 $P-V$ 曲線から得られた葉の水分生理特性は，枯死直前の春〜初夏まで正常な季節変化 を示して，細胞壁弾性率 $(\varepsilon)$ には変化が認められなかった。

(Received June 20, 1988)

8) Kaufmann, M.R. and Thor, G.L. (1982). Can. J. For. Res. 12: 969-972. 9) O'Neill, S.D. (1983). Plant Physiol. 72: 938-944. 10) Doi, K., Morikawa, Y. and Hinckley, T.M. (1986). Can. J. For. Res. 16: 74-77. 